\title{
In vivo induction of hepatocellular carcinoma by diethylnitrosoamine and pharmacological intervention in Balb C mice using Bergenia ciliata extracts
}

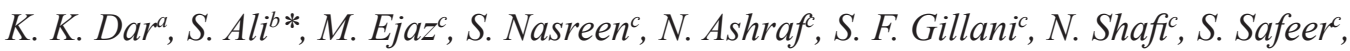 \\ M. A. Khan ${ }^{c, d}$, S. Andleeb ${ }^{c}$ and T. A. Mughal \\ ${ }^{a}$ College of Life Science and Technology, Beijing University of Chemical Technology, 100029, Beijing, China \\ ${ }^{b}$ Department of Zoology, Government College University Lahore, Lahore-54000, Pakistan \\ ${ }^{\mathrm{c}}$ Microbial Biotechnology and Medical Toxicology Laboratory, Department of Zoology, University of Azad Jammu and \\ Kashmir, Muzaffarabad-13100, Pakistan \\ ${ }^{\mathrm{d}}$ School of Material Science and Engineering - MSE, Nanyang Technological University, Singapore \\ *e-mail: shaukatali134@yahoo.com
}

Received: October 16, 2017 - Accepted: March 22, 2018 - Distributed: November 30, 2019

(With 3 figures)

\begin{abstract}
Background: Hepatocellular carcinoma is the most frequent primary malignancy of liver and accounts for as many as one million deaths worldwide in a year. Objectives: The aim of the present study was to evaluate the anti-cancerous efficiency of Bergenia ciliata rhizome against diethylnitrosoamine induced hepatocarcinogenesis in Balb C mice. Methods: One percent diethylnitrosoamine was prepared by using $99 \mathrm{ml}$ of normal saline $\mathrm{NaCl}$ ( 0.9 percent) solution to which was added $1 \mathrm{ml}$ of concentrated diethylnitrosoamine (DEN) solution $(0.01 \mu \mathrm{g} / \mu \mathrm{l})$. Extract of Bergenia ciliata was prepared by maceration technique. Mice were classified into four groups as follows: Group 1 a control group ( $N=7)$ received saline solution $(3.5 \mu \mathrm{l} / \mathrm{mg})$, group $2(\mathrm{~N}=14)$ received diethylnitrosoamine $(3.5 \mu \mathrm{l} / \mathrm{mg})$ intraperitoneally once in a week for eight consecutive weeks, group $3(\mathrm{~N}=7)$ received plant extract $(150 \mathrm{mg} / \mathrm{kg}$ (Body weight)) once in a week, while group $4(\mathrm{~N}=7)$ was given combination of diethylnitrosoamine $(3.5 \mu \mathrm{l} / \mathrm{mg})$ and plant extract $(150 \mathrm{mg} / \mathrm{kg}$ (Body weight)). After eight weeks of DEN induction group 2 mice were divided into two subgroups containing seven mice each, subgroup 1 was sacrificed while subgroup 2 was treated with plant extract ( $150 \mathrm{mg} / \mathrm{kg}$ (Body weight)) once in a week for eight consecutive weeks. Results: The model of DEN injected hepatocellular carcinomic (HCC) mice elicited significant decline in levels of albumin with concomitant significant elevations in tumor markers aspartate aminotransferase, alanine aminotransferase (ALT), lactate dehydrogenase (LDH), alpha feto protein (AFP), gamma glutamyl transferase (Y-GT), 5 nucleotidase (5NT), glucose-6-phosphate dehydrogenase (G6PDH) and bilirubin. The intraperitoneal administration of $B$. ciliata as a protective agent, produced significant increase in albumin levels with significant decrease in the levels of tumor markers aspartate aminotransferase (AST), alanine aminotransferase (ALT), lactate dehydrogenase (LDH), alpha feto protein (AFP), gamma glutamyl transferase (Y-GT), 5 nucleotidase (5NT), glucose-6-phosphate dehydrogenase (G6PDH) and bilirubin. Conclusion: Bergenia ciliata has potent antioxidant activity, radical scavenging capacity and anticancerous properties. Bergenia ciliata extracts may provide a basis for development of anti-cancerous drug.
\end{abstract}

Keywords: hepatocellularcarcinoma, diethylnitrosoamine, Balb C mice, anti-cancerous activity, Bergenia ciliata, alpha feto protein.

\section{Indução in vivo de carcinoma hepatocelular por dietilnitrosoamina e intervenção farmacológica em camundongos balb c usando extratos de Bergenia ciliata}

\section{Resumo}

Antecedentes: O carcinoma hepatocelular é a neoplasia primária mais frequente do fígado e é responsável por até um milhão de mortes em todo o mundo em um ano. Objetivos: O objetivo do presente estudo foi avaliar a eficiência anticancerígena do rizoma de Bergenia ciliata contra a hepatocarcinogênese induzida por dietilnitrosoamina em camundongos balb c. Métodos: Um por cento de dietilnitrosoamina foi preparado usando 99 ml de solução salina normal $(0,9$ por cento) à qual foi adicionado $1 \mathrm{ml}$ de solução concentrada de dietilnitrosoamina $(\mathrm{DEN})(0,01 \mu \mathrm{g} / \mu \mathrm{l})$. $\mathrm{O}$ extrato de Bergenia ciliata foi preparado pela técnica de maceração. Os ratos foram classificados em quatro grupos: 
Grupo 1 grupo controle $(\mathrm{N}=7)$ recebeu solução salina $(3,5 \mathrm{~mL} / \mathrm{mg})$, grupo $2(\mathrm{~N}=14)$ recebeu dietilnitrosoamina $(3,5 \mathrm{~mL} / \mathrm{mg})$ por via intraperitoneal uma vez por semana para oito semanas consecutivas, o grupo $3(\mathrm{~N}=7)$ recebeu extrato vegetal $(150 \mathrm{mg} / \mathrm{kg}$ (peso corporal)) uma vez por semana, enquanto o grupo $4(\mathrm{~N}=7)$ recebeu combinação de dietilnitrosoamina $(3,5 \mu \mathrm{l} / \mathrm{mg}$ ) e extrato $(150 \mathrm{mg} / \mathrm{kg}$ (peso corporal). Após oito semanas do grupo de indução DEN 2 ratos foram divididos em dois subgrupos contendo sete ratos cada, subgrupo 1 foi sacrificado enquanto subgrupo 2 foi tratado com extrato vegetal $(150 \mathrm{mg} / \mathrm{kg}))$ uma vez por semana durante oito semanas consecutivas. Resultados: $\mathrm{O}$ modelo de camundongos hepatocelulares carcinômicos (CHC) injetados com DEN provocou declínio significativo nos níveis de albumina com elevações significativas concomitantes nos marcadores tumorais: aspartato aminotransferase, alanina aminotransferase (ALT), lactato desidrogenase (LDH), proteína alfa feto (AFP), gama glutamiltransferase (Y-GT), 5 nucleotidase (5NT), glicose-6-fosfato ehidrogenase (G6PDH) e bilirrubina. A administração intraperitoneal de B. ciliata como agente protetor produziu um aumento significativo nos níveis de albumina com uma diminuição significativa nos níveis dos marcadores tumorais: aspartato aminotransferase, alanina aminotransferase (ALT), lactato desidrogenase (LDH), proteína alfa feto (AFP), gama glutamiltransferase (Y-GT), 5 nucleotidase (5NT), glicose-6-fosfato desidrogenase (G6PDH) e bilirrubina. Conclusão: Bergenia ciliata possui atividade antioxidante potente, capacidade de eliminação de radicais livres e propriedades anticancerígenas. Extratos de Bergenia ciliata podem fornecer uma base para o desenvolvimento de drogas anti-cancerígenas.

Palavras-chave: carcinoma hepatocelular, dietilnitrosoamina, camundongos Balb c, atividade anticancerosa, Bergenia ciliata, proteína alfa feto.

\section{Introduction}

Liver comprises about $2.5 \%$ of an adult's body weight and is the largest internal organ as well as gland in the body. It performs many important functions in the body such as xenobiotic and drug metabolism, energy metabolism, protein and amino acid metabolism, storage of glucose in the form of glycogen, storage of vitamins and regulation of hormonal functions (Rhoades and Bell, 2013). Hepatocellular carcinoma (HCC) is the most frequent form of primary liver cancer, it is one of the most common life threatening solid tumors with global annual diagnosis exceeding one million new cases and remains the third leading cause of cancer death (Jemal et al., 2007). Causes of liver cancer include Hepatitis B virus (El-Serag and Rudolph, 2007; Mcmahon et al., 1990), Hepatitis C virus (Ikeda et al., 1999; Bruno et al., 2001), alcohol (Donato et al.,2002), aflatoxin (Turner et al., 2002), vinyl chloride (Wolk et al., 2001), obesity (Cotrim et al., 2000) and oral contraceptives (Yu and Yuan, 2004).

Diethylnitrosamine (DEN) is amongst the most essential natural carcinogenic agents, which is known to cause changes in the enzymes required in DNA repair replication and is regularly utilized as a cancer-causing agent to prompt liver carcinogenesis in mouse models (Ramakrishnan et al., 2007). Compounds like N-nitroso are well established hepatocarcinogens that are being implicated in the etiology of various human cancers (Bansal et al., 2005). DEN is a potent hepatocarcinogenic nitrosamine present in tobacco smoke, water, cheddar cheese, cured and fried meals, occupational settings, cosmetics, agricultural chemicals and pharmaceutical agents and is considered as potential hazard for the development of disease (Bartsch and Montesano, 1984).

Reliable markers for HCC diagnosis are aspartate transaminases (AST) and alanine transaminases (ALT) (Whittby et al., 1984), lactate dehydrogenase (LDH) (King, 1965), bilirubin (Harper, 1961), Gamma-glutamyl transferase (GGT) (Yao et al., 2004), alpha feto protein (Sell and Becker, 1978), 5-nucleotidase (5NT) (Sadej et al., 2006), Glucose-6-phosphate dehydrogenase (G6PDH) (Molero et al., 1994) and albumin (Vandenberghe, 1996).

Chemotherapeutic drugs are not recommended for advanced stage HCC treatment because these are chemo-refractory and have adverse events (AEs). The toxicity caused by these chemotherapeutic agents has restricted their usage (Deng et al., 2015). Sorafenib is a multikinase inhibitor that targets the serine-threonine kinase Raf-1 of the Ras/MAPK pathway in addition to having antiangiogenic properties. Besides this Sorafenib also have side effects like, diarrhoea, hand foot syndrome and hypertension. Gemcitabine has a favorable toxicity profile, with bone marrow suppression being the most common side effect (Chung, 2015).

Numerous naturally occurring compounds from plants are being used as anticancerous agents and are currently undergoing medical development. Many plants like Petasites japonicas (Kim et al., 2015), Amorphophallus campanulatus (Ansil et al., 2012), Curcuma aromatic (Li et al., 2014), Panax ginseng, Salvia miltiorrhiza (Wang et al., 2012), Tripterygium wilfordii (Chen et al., 2012), Astragalus (Chen et al., 2011) and many other plants are used against $\mathrm{HCC}$ as an anticancerous agents with low toxicity. Bergenia ciliata $(\mathrm{BC})$ belongs to family Saxifragaceae has various medicinal properties. These properties include antibacterial, antioxidant, anti-inflammatory, anti-diabetics and antiviral activities (Ruby et al., 2012). Bergenia ciliata also aids in removing kidney stones (Hafidh et al., 2009).

The aim of current study was to assess the anti-cancerous activity of Bergenia ciliata rhizome in Balb C mice against DEN induced hepatocellular carcinoma. The use of natural herbs such as $B$. ciliata will result in decreased toxicity and side effects. Thus, it will increase safety and hence patients associated compliance resulting in overall increase in effectiveness. 


\section{Materials and Methods}

The Minimum Standards of Reporting Checklist contains details of the experimental design, statistics, and resources used in this study.

\subsection{Ethical statement}

All animal trial techniques were directed as per local and worldwide controls. The nearby direction is the Wet op de dierproeven (Article 9) of Dutch Law (international) and a similar law regulated by the Bureau of Animal Experiment Licensing, local University.

\subsection{Chemicals used}

All the chemicals used were of analytical grade. Diehtylnitrosoamine (Sigma Chemical Co, St Louis, Mo, USA) and normal saline ( $\mathrm{NaCl} 0.9$ percent $\mathrm{w} / \mathrm{v})$ were used.

\subsection{Animals}

Balb C mice (35-40 g) of male sex were obtained from the animal house in National Institute of Health (NIH) Islamabad, Pakistan. The animals were maintained in a separate room having temperature $20-23^{\circ} \mathrm{C}$ and $50 \%-60 \%$ relative humidity with $12: 12 \mathrm{~h}$ light/dark cycle in polypropylene cages. The animals were fed with standard rodent pellet diet and drinking water. Food was withdrawn 18-24 $\mathrm{h}$ before the experiment although water was allowed ad libitum and allocated to different experimental groups.

\subsection{Preparation of diethylnitrosoamine}

One percent diethylnitrosoamine was prepared by using $99 \mathrm{ml}$ of normal saline $\mathrm{NaCl}$ ( 0.9 percent $)$ solution to which was added $1 \mathrm{ml}$ of concentrated diethylnitrosoamine (DEN) solution $(0.01 \mu \mathrm{g} / \mu \mathrm{l})$.

\subsection{Diethylnitrosoamine induced hepatocellular carcinoma}

Male Balb C mice (35-40 g) were divided into four groups. Group 1 a control group $(\mathrm{N}=7)$ received saline solution $(3.5 \mu \mathrm{l} / \mathrm{mg})$, group $2(\mathrm{~N}=14)$ received diethylnitrosoamine (3.5 $\mu \mathrm{l} / \mathrm{mg})$ intraperitoneally once in a week for eight consecutive weeks, group $3(\mathrm{~N}=7)$ received plant extract $(150 \mathrm{mg} / \mathrm{kg})$ once in a week, while group $4(\mathrm{~N}=7)$ was given combination of diethylnitrosoamine $(3.5 \mu \mathrm{l} / \mathrm{mg})$ and plant extract $(150 \mathrm{mg} / \mathrm{kg})$.

\subsection{Plant material and extract preparation}

Rhizome of Bergenia ciliata was collected from Jhellum valley Azad Kashmir, Pakistan and washed under running tap water, air dried under shade, coarsely powdered and kept in airtight container for further use. Powder of rhizome was soaked in methanol for 20 days to increase the polarity at room temperature $\left(25^{\circ} \mathrm{C}-30^{\circ} \mathrm{C}\right)$. Extract was prepared through maceration extraction method. The crude extract was filtered through Whatmann filter paper I (Sigma Aldrich), evaporated under reduced pressure using rotary evaporator (Temp, $37^{\circ} \mathrm{C}$ and at speed of $100 \mathrm{rpm}$ ) to get the required concentration. The extract was then dissolved in water and methanol in proportion of 23:1 respectively for screening anti-cancer assay.

\subsection{Toxicity studies}

Assessment of toxicity studies were conducted by utilizing the acute toxic classic method (Hussain et al., 2012). For each step, three male Balb C mice were used in this study. The mice were kept fasting with water overnight and extract was administered intraperitoneally at a single dose of $150 \mathrm{mg} / \mathrm{kg}$. Mice were regularly observed for $4 \mathrm{~h}$ after initial administration and then once in a day for consecutive two weeks. If the mortality occurred in two out of three mice than the dose was toxic, if not than this dose was used as standard. Mice survived at the dose of $150 \mathrm{mg} / \mathrm{kg}$ and this dose was used as a standard in the whole experiment.

\subsection{In vivo pharmacological interventions against hepatocellular carcinoma}

After eight weeks of DEN induction group 2 mice were divided into two subgroups containing seven mice each, subgroup 1 was sacrificed while subgroup 2 was treated with plant extract $(150 \mathrm{mg} / \mathrm{kg})$ once in a week for eight consecutive weeks.

\subsection{Biochemical analysis}

After the last treatment, the mice were fastened overnight, and all of the mice were anesthetized with chloroform presented on a cotton ball and euthanized by cervical decapitation. Ethylene diamine tetra acetic acid (EDTA) tubes (size $13 * 75$, containing $\sim 1.8 \mathrm{mg}$ K2EDTA per ml blood) were used for collection of blood samples. Blood samples were centrifuged for a minimum of 10 minutes at 1000-2000 RCF (Relative Centrifugal Force). Centrifuged plasma was used for various biochemical measurements. The livers were extracted instantly from the mice, washed with ice-chilled physiological saline and refrigerated until examination.

The activities of biochemical parameters like aspartate transaminase (AST) and alanine transaminase (ALT) were estimated by the method of (Reitman and Frankel, 1957), while Gamma glutamyl transferase (Y-GT) was estimated by methods of (Szasz, 1976; King, 1965). Total bilirubin level (TBL) was determined by modified dimethyl sulfoxide (DMSO) method (Dangerfield and Finlayson, 1953) on the basis of sulfanilic acid reaction with sodium nitrite to produce deoxidized sulfanilic acid. Activity of lactate dehydrogenase (LDH) was assessed by the method described by (King, 1965), while total albumin levels were measured by procedure demonstrated by (Savory et al., 1976). Activity of 5 nucleotidase (5NT) was measured by the process explained by (Rieder and Otero, 1969). G6DPH was assessed by the method explained by (Minucci et al., 2009). Quantitative estimation of tumor marker alpha fetoprotein (AFP) antigen (CEA) was based on solid phase enzyme linked immunosorbent assay using the UBI MAGIWELL (USA) enzyme immunoassay kit (Macnab et al., 1978; Sell and Becker, 1978). Activity of G6PDH was assessed by the method explained by (Tepperman and Tepperman, 1962) 


\subsection{Statistical analysis}

Statistical analyses were performed using GraphPad Prism for Windows (version 5.03) and also used to plot graphs with error bars of standard errors of the means (SEM). To analyse the impact of different treatments on levels of biomarkers in mice, one-way analysis of variance and a Dunnett's multiple comparison test with probability level of five percent as the minimal criterion of significance was used.

\section{Results}

\subsection{Effect of BC extract on body weight, liver weight and relative liver weight}

Table 1 depicts initial and final average body weight, absolute and relative liver weights of different treatment groups. Final body weight of the control group I mice was $(244.85 \pm 0.98) \mathrm{g}$ which on administration of DEN was significantly decreased to $(172.57 \pm 0.68) \mathrm{g}$ in group II mice. In mice group IV treated with BC extract $(150 \mathrm{mg} / \mathrm{kg})$ after DEN induction, the weight of mice showed significant increase in weight $(210.28 \pm 1.84) \mathrm{g}$ when compared to group II DEN treated mice. Further, the group II intraperitoneally DEN administered mice resulted in significant increase of relative liver weight $/ 100 \mathrm{~g}$ body weight to $(5.47 \pm 0.06) \mathrm{g}$ as compared to control, $(2.94 \pm 0.01) \mathrm{g}$. The treatment with BC extract in group V DEN administered mice significantly decreased the relative liver weight $(3.52 \pm 0.008)$. While concomitant administration of DEN and BC extract resulted in maintaining the body weight $(240.57 \pm 1.2) \mathrm{g}$ and relative liver weight $(2.63 \pm 0.01) \mathrm{g}$ as compared to $\mathrm{DEN}$ administered mice. The administration of BC extract alone did not show any significant effect on body weight and relative liver weight Table 1.

\subsection{Effect of BC extract on HCC tumour markers}

\subsubsection{Effect on ALT}

Intraperitoneal administration of DEN $(3.5 \mu \mathrm{l} / \mathrm{mg}$ body weight once in a week for eight consecutive weeks in mice) caused highly significant increase in levels of ALT (control: $29.0 \pm 1.8 \mathrm{U} / \mathrm{L}$; DEN: $141.5 \pm 2.2 \mathrm{U} / \mathrm{L}$; $\mathrm{BC}: 32.7 \pm 3.2 \mathrm{U} / \mathrm{L})$. When extract of $\mathrm{BC}$ was given in combination with DEN no significant increase in levels of ALT was observed (DEN+BC1: 49.1 $\pm 3.6 \mathrm{U} / \mathrm{L})$. When extract of B. ciliata (BC) was injected intraperitoneally $(150 \mathrm{mg} / \mathrm{kg}$ body weight once in a week for eight consecutive weeks) in DEN treated mice, significant decrease in level of ALT (DEN: $141.5 \pm 2.2 \mathrm{U} / \mathrm{L} ; \mathrm{DEN}+\mathrm{BC} 2: 124.0 \pm 3.4 \mathrm{U} / \mathrm{L}$ ) was observed (Figure 1.A).

\subsubsection{Effect on AST}

Intraperitoneal injection of DEN (3.5 $\mu 1 / \mathrm{mg}$ body weight once in a week for eight consecutive weeks in mice) showed tremendous increase in levels of AST (control: 87.9 $\pm 2.7 \mathrm{U} / \mathrm{L} ; \mathrm{DEN}$ : $474.0 \pm 7.6 \mathrm{U} / \mathrm{L}: \mathrm{BC}: 93.2 \pm 3.5$ ). When extract of $\mathrm{BC}$ was given in combination with DEN no significant increase in levels of AST was observed $(\mathrm{DEN}+\mathrm{BC} 1: 138 \pm 2.7 \mathrm{U} / \mathrm{L})$. But, intraperitoneal administration of extract of BC $(150 \mathrm{mg} / \mathrm{kg}$ body weight once in a week for eight consecutive weeks) in DEN treated mice, resulted in significant decrease in level of AST (DEN: 474.0 \pm 7.6 U/L; DEN + BC2: $439.3 \pm 10.4 \mathrm{U} / \mathrm{L}$ ) (Figure 1).

\subsubsection{Effect on $\mathrm{LDH}$}

DEN injected intraperitoneally $(3.5 \mu \mathrm{l} / \mathrm{mg}$ body weight once in a week for eight consecutive weeks in mice) resulted in highly significant increase in levels of LDH (control: $373.2 \pm 15.0 \mathrm{U} / \mathrm{L}$; DEN: $2165.7 \pm 78.9 \mathrm{U} / \mathrm{L}$; $\mathrm{BC}: 426.2 \pm 15.8$ ) When extract of $\mathrm{BC}$ was given in combination with DEN no significant increase in levels of LDH was observed (DEN + BC1: $568.9 \pm 28.5 \mathrm{U} / \mathrm{L})$. But, intraperitoneal administration of extract of $\mathrm{BC}$ $(150 \mathrm{mg} / \mathrm{kg}$ body weight once in a week for eight consecutive weeks) in DEN treated mice, resulted in significant decrease in level of LDH (DEN: $2165.7 \pm 78.9 \mathrm{U} / \mathrm{L}$; $\mathrm{DEN}+\mathrm{BC} 2: 1835.0 \pm 112.2 \mathrm{U} / \mathrm{L})$ to significant value (Figure 1).

\subsubsection{Effect on AFP}

Highly significant increase in levels of tumour marker AFP was caused by DEN $(3.5 \mu \mathrm{l} / \mathrm{mg}$ body weight in mice) once in a week for eight consecutive weeks (control: $13.5 \pm 0.9 \mathrm{ng} / \mathrm{ml}$; DEN: $63.4 \pm 2.4 \mathrm{ng} / \mathrm{ml}$; $\mathrm{BC}: 14.9 \pm 0.6 \mathrm{ng} / \mathrm{ml}$ ). When extract of $\mathrm{BC}$ was given in combination with DEN no significant increase in levels of AFP was observed (DEN + BC1: $35.4 \pm 2.6 \mathrm{ng} / \mathrm{ml}$ ). Significant decrease in level of AFP (DEN: $63.4 \pm 2.4 \mathrm{ng} / \mathrm{ml}$; $\mathrm{DEN}+\mathrm{BC} 2: 54.0 \pm 3.0 \mathrm{ng} / \mathrm{ml})$ was seen after intraperitoneal induction of extract of RBC $(150 \mathrm{mg} / \mathrm{kg}$ body weight once in a week for eight consecutive weeks) in DEN treated mice (Figure 2).

Table 1. Effect of Bergenia ciliate extract on the body weight, liver and relative liver weight of different mice groups.

\begin{tabular}{cccccc}
\hline Group & Treatment & $\begin{array}{c}\text { Initial body } \\
\text { weight }(\mathbf{g})\end{array}$ & $\begin{array}{c}\text { Final body } \\
\text { weight } \mathbf{( g )}\end{array}$ & Liver weight (g) & $\begin{array}{c}\text { Relative liver weight } \\
\text { (Liver wt./100 g b. w.) }\end{array}$ \\
\hline I & Control & $156.42 \pm 1.10$ & $244.85 \pm 0.98$ & $7.0 \pm 0.06$ & $2.94 \pm 0.01$ \\
II & DEN & $154.71 \pm 1.56$ & $172.57 \pm 0.68^{* * *}$ & $9.16 \pm 0.07$ & $5.47 \pm 0.06^{* * * *}$ \\
III & BC & $154 \pm 0.9$ & $245.15 \pm 0.96$ & $6.18 \pm 0.09$ & $2.80 \pm 0.01$ \\
IV & DEN+BC1 & $155.28 \pm 1.5$ & $240.57 \pm 1.25^{@ @ @ ~}$ & $6.03 \pm 0.09$ & $2.63 \pm 0.01^{@ @ @ ~}$ \\
V & DEN+BC2 & $156.28 \pm 1.18$ & $210 \pm 1.84^{@ @ @ ~}$ & $7.82 \pm 0.05$ & $3.52 \pm 0.008^{@ @ @ ~}$ \\
\hline
\end{tabular}

Values are expressed as mean \pm SEM of 7 mice in each group. ${ }^{* * *} \mathrm{p} \leq 0.001$ compared to respective control group I. ${ }^{@ @ @ ~} \mathrm{p} \leq 0.001$ compared with group II (DEN treated). 
ALAT

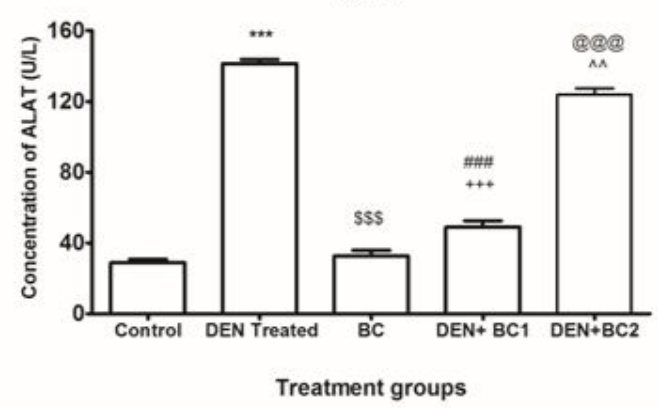

ASAT

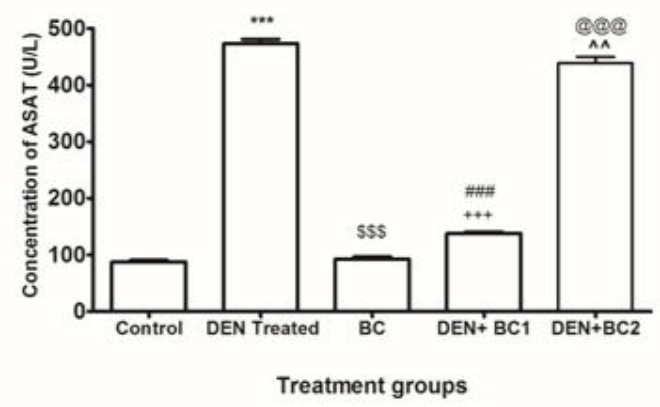

LDH

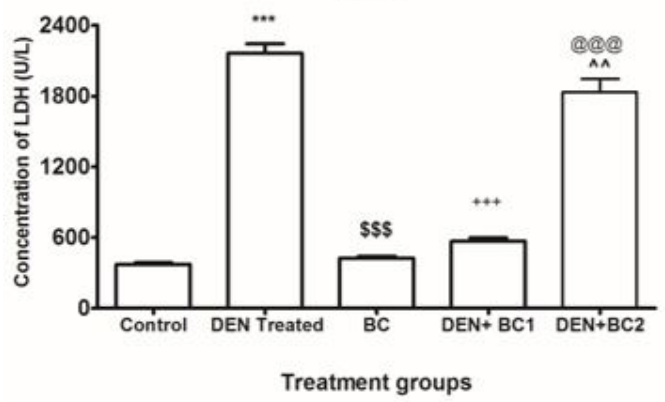

Figure 1. Analysis of Alanine Transaminase (ALAT), Aspartate Transaminase (ASAT) and Lactate Dehydrogenase (LDH). Keys: DEN, Diethylnitrosoamine; BC, extract of Bergenia ciliata; DEN+BC1, DEN and BC given at a time; $\mathrm{DEN}+\mathrm{BC} 2$, treatment of $\mathrm{DEN}$ injected mice after eight weeks using $\mathrm{BC}$ *depicts differences between control and DEN treatment groups. "depicts differences between control and $\mathrm{BC} 1$ extract treatment groups. ${ }^{\circledR}$ depicts differences between control and $\mathrm{BC} 2$ extract treatment groups. ${ }^{\text {sdepicts }}$ differences between DEN and BC extract treatment groups. ${ }^{+}$depicts differences between $\mathrm{DEN}$ and $\mathrm{BC} 1$ extract treatment groups. 'depicts differences between DEN and BC2 extract treatment groups. Each bar represents the mean value of seven replicates and SEM. Statistical icon ${ }^{\wedge}=p \leq 0.01,{ }^{+++}$, \#\#, @@@, ***, $\$ \$ s=p \leq 0.001$.

\subsubsection{Effect on Albumin}

Albumin level was significantly decreased (control: $6.2 \pm 0.4 \mathrm{U} / \mathrm{L}$; DEN: $2.8 \pm 0.2 \mathrm{U} / \mathrm{L}$; BC: $6.1 \pm 0.4 \mathrm{U} / \mathrm{L}$ ) by intraperitoneal administration of DEN $(3.5 \mu 1 / \mathrm{mg}$ body weight once in a week for eight consecutive weeks

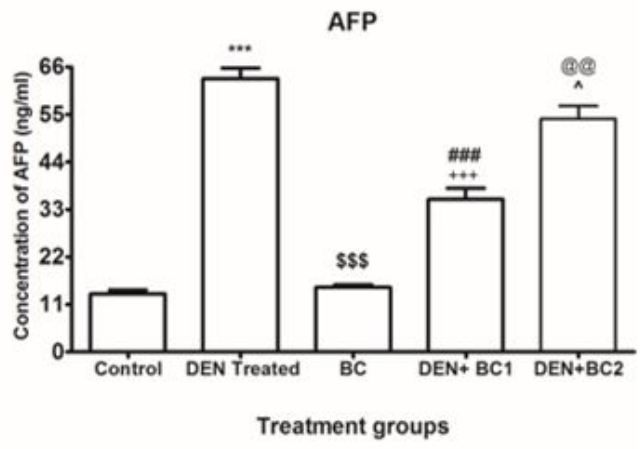

Bilirubin
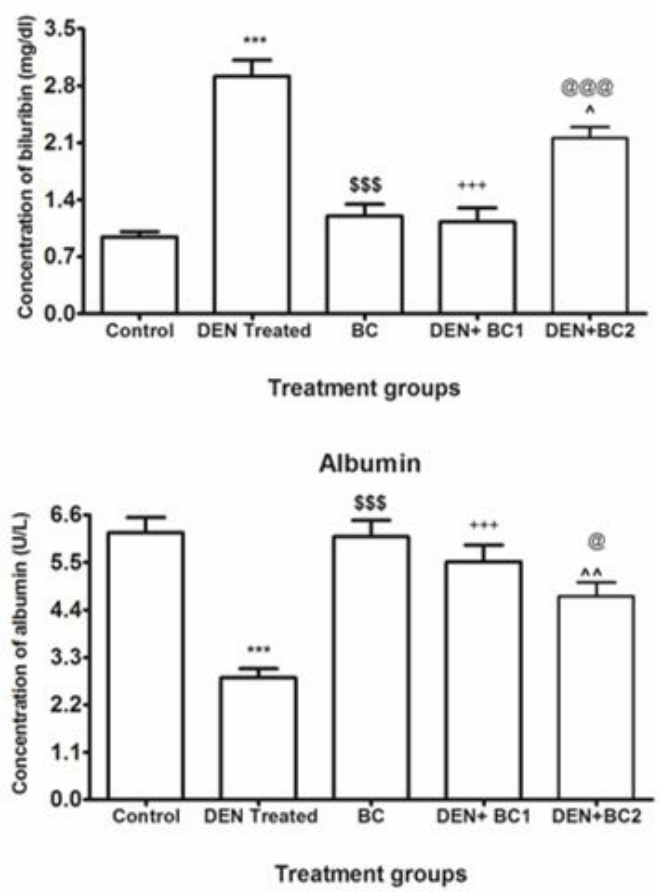

Figure 2. Analysis of Alpha Fetoprotein (AFP), Bilirubin and Albumin. Keys: DEN, Diethylnitrosoamine; BC, extract of Bergenia ciliata; DEN+BC1, DEN and $\mathrm{BC}$ given at a time; $\mathrm{DEN}+\mathrm{BC} 2$, treatment of $\mathrm{DEN}$ injected mice after eight weeks using $\mathrm{BC} *$ depicts differences between control and DEN treatment groups. "depicts differences between control and $\mathrm{BC} 1$ extract treatment groups. ${ }^{a}$ depicts differences between control and $\mathrm{BC} 2$ extract treatment groups. "depicts differences between DEN and BC extract treatment groups. ${ }^{+}$depicts differences between DEN and $\mathrm{BC} 1$ extract treatment groups. ^depicts differences between DEN and BC2 extract treatment groups. Each bar represents the mean value of seven replicates and SEM. Statistical icon: ${ }^{@}, \wedge=p \leq 0.05,{ }^{\circledR}, \wedge$ ^ ${ }^{\wedge}=0.01,{ }^{+++}$, \#\#, $@ @ @, * * *$, $\$ \$ \$=p \leq 0.001$.

in mice). When extract of $\mathrm{BC}$ was given in combination with DEN no significant decrease in levels of albumin was observed (DEN + BC1: $5.5 \pm 0.4 \mathrm{U} / \mathrm{L})$. But intraperitoneal induction of extract of BC $(150 \mathrm{mg} / \mathrm{kg}$ body weight once in a week for eight consecutive weeks) in DEN treated 
mice, resulted in significant increase in level of albumin (DEN: $2.8 \pm 0.2 \mathrm{U} / \mathrm{L} ; \mathrm{RBC}: 4.7 \pm 0.3 \mathrm{U} / \mathrm{L}$ ) (Figure 2).

\subsubsection{Effect on Bilirubin}

Level of bilirubin was also significantly increased (control: $0.9 \pm 0.1 \mathrm{mg} / \mathrm{dl}$; DEN: $2.9 \pm 0.2 \mathrm{mg} / \mathrm{dl} ; \mathrm{BC}: 1.2 \pm 0.1 \mathrm{mg} / \mathrm{dl})$ when DEN (3.5 $\mu 1 / \mathrm{mg}$ body weight once in a week for eight consecutive weeks in mice) was injected intraperitoneally. When extract of BC was given in combination with DEN no significant increase in levels of bilirubin was observed $(\mathrm{DEN}+\mathrm{BC} 1: 1.1 \pm 0.2 \mathrm{U} / \mathrm{L})$. Intraperitoneal administration of extract of BC $(150 \mathrm{mg} / \mathrm{kg}$ body weight once in a week for eight consecutive weeks) in DEN treated mice, caused significant decrease in level of bilirubin (DEN: $2.9 \pm 0.2 \mathrm{mg} / \mathrm{dl}$; $\mathrm{DEN}+\mathrm{BC} 2: 2.2 \pm 0.1 \mathrm{mg} / \mathrm{dl}$ ) (Figure 2).

\subsubsection{Effect on Y-GT}

Intraperitoneal injection of DEN $(3.5 \mu \mathrm{l} / \mathrm{mg}$ body weight once in a week for eight consecutive weeks in mice) caused highly significant increase in levels of Y-GT (control: $38.2 \pm 1.6 \mathrm{U} / \mathrm{L} ; \mathrm{DEN}$ : $146.8 \pm 2.6 \mathrm{U} / \mathrm{L} ; 43.7 \pm 2.1$ ). When extract of $\mathrm{BC}$ was given in combination with DEN no significant increase in levels of Y-GT was observed $(\mathrm{DEN}+\mathrm{BC} 1: 57.7 \pm 2.2 \mathrm{U} / \mathrm{L})$. But, intraperitoneal injection of extract of BC $(150 \mathrm{mg} / \mathrm{kg}$ body weight once in a week for eight consecutive weeks) in DEN treated mice, decreased the level of Y-GT (DEN: $146.8 \pm 2.6 \mathrm{U} / \mathrm{L} ; \mathrm{DEN}+\mathrm{BC} 2$ : $132.8 \pm 3.5 \mathrm{U} / \mathrm{L}$ ) to a significant level (Figure 3).

\subsubsection{Effect on $5 \mathrm{NT}$}

5 NT level was significantly increased (control: $5.3 \pm 0.3 \mathrm{U} / \mathrm{L}$; DEN: $16.3 \pm 0.7 \mathrm{U} / \mathrm{L}$; BC: $4.9 \pm 0.2 \mathrm{U} / \mathrm{L})$ in mice by intraperitoneal induction of DEN $(3.5 \mu \mathrm{l} / \mathrm{mg}$ body weight once in a week for eight consecutive weeks). When extract of $\mathrm{BC}$ was given in combination with DEN no significant increase in levels of $5 \mathrm{NT}$ was observed $(\mathrm{DEN}+\mathrm{BC} 1: 6.9 \pm 0.4 \mathrm{U} / \mathrm{L})$. But when extract of BC was administered intraperitoneally $(150 \mathrm{mg} / \mathrm{kg}$ once in a week for eight consecutive weeks) in DEN treated mice, significant decrease in levels of $5 \mathrm{NT}$ (DEN: $16.3 \pm 0.7 \mathrm{U} / \mathrm{L}$; $\mathrm{DEN}+\mathrm{BC} 2: 13.4 \pm 0.8 \mathrm{U} / \mathrm{L}$ ) was seen (Figure 3).

\subsubsection{Effect on G6PDH}

Intraperitoneal induction of DEN $(3.5 \mu \mathrm{l} / \mathrm{mg}$ body weight once in a week for eight consecutive weeks in mice) caused highly significant increase in level of G6PDH (control: $4.1 \pm 0.3 \mathrm{mU} / \mathrm{ml}$; DEN: $13.7 \pm 0.4 \mathrm{mU} / \mathrm{ml}$; $\mathrm{BC}: 5.9 \pm 0.2 \mathrm{mU} / \mathrm{ml}$ ). When extract of $\mathrm{BC}$ was given in combination with DEN no significant decrease in levels of G6PDH was observed (DEN + BC1: $6.9 \pm 0.5 \mathrm{mU} / \mathrm{ml}$ ). G6PDH level was significantly decreased (DEN: $13.7 \pm 0.4 \mathrm{mU} / \mathrm{ml}$; $\mathrm{DEN}+\mathrm{BC} 2: 11.6 \pm 0.5 \mathrm{mU} / \mathrm{ml})$ when extract of $\mathrm{BC}$ was given intraperitoneally $(150 \mathrm{mg} / \mathrm{kg}$ body weight once in a week for eight consecutive weeks) in DEN treated mice (Figure 3).

\section{Discussion}

DEN (diethylnitrosoamine) is a well-known heptocarcinogen. Metabolic biotransformation of DEN produces promutagenic products $\mathrm{O}^{6}$-ethyldeoxyguanosine
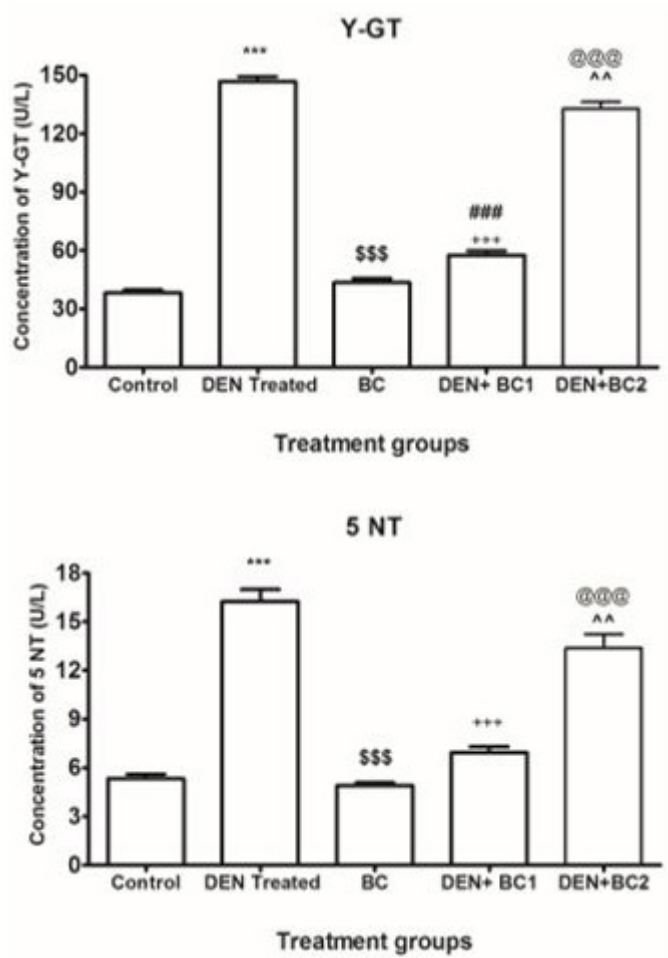

G6PDH

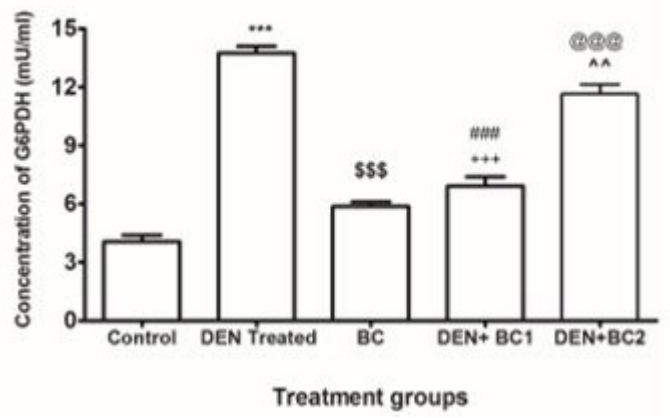

Figure 3. Analysis of Gamma Glutamyl Transferase (Y-GT), 5-Nucleotidase (5 NT) and Glucose 6 Phosphate Dehydrogenase(G6PDH). Keys: DEN, Diethylnitrosoamine; $\mathrm{BC}$, extract of Bergenia ciliata; DEN+BC1, DEN and BC given at a time; $\mathrm{DEN}+\mathrm{BC} 2$, treatment of $\mathrm{DEN}$ injected mice after eight weeks using $\mathrm{BC}$ *depicts differences between control and DEN treatment groups. "depicts differences between control and $\mathrm{BC} 1$ extract treatment groups. ${ }^{\text {a }}$ depicts differences between control and $\mathrm{BC} 2$ extract treatment groups. ${ }^{\$}$ depicts differences between DEN and BC extract treatment groups. ${ }^{+}$depicts differences between DEN and $\mathrm{BC} 1$ extract treatment groups. ^depicts differences between DEN and BC2 extract treatment groups. Each bar represents the mean value of seven replicates and SEM. Statistical icon: ${ }^{\wedge \wedge}=p \leq 0.01,{ }^{+++}$, @@@, ${ }^{\# \#+* * *},{ }^{\$ \$ \$}=p \leq 0.001$.

$\mathrm{O}^{4}$ and $\mathrm{O}^{6}$ ethyldeoxythymidine which are responsible for the carcinogenic effect (Hussain et al., 2012; Usunomena et al., 2012).DEN administration results in leakage of transaminases and LDH which represents hepatocyte damage. Mice group 
with DEN induction demonstrated a significant increment in serum transaminases ALT, AST and LDH activities. Over generation of these proteins in tumor cells, is due to alterations caused by DEN in the permeability of cell membrane thus, bringing about leakage of these proteins into serum (Ramakrishnan et al., 2007). The increment of these enzymatic activities was characteristic of the toxic effects of DEN on the liver tissue. It is referred to that $\mathrm{N}$-nitroso compounds have been found as cancer causing agents in different warm blooded animals including primates (Swenberg et al., 1991). DEN has been appeared to be processed by cytochrome P-450 (CYP 2E1) to its dynamic ethyl radical metabolite, which interacts with DNA causing change and carcinogenesis (Anis et al., 2001). Discoveries of present research were consistent with the findings of (Ramakrishnan et al., 2007; Swenberg et al., 1991; Mittal et al., 2006; Vozarova et al., 2002). Then again, extract of $B$. ciliata rhizome significantly reduced the elevated activities of these proteins which may be because of the capacity of constituents in B. ciliata to maintain parenchymal cell recovery in liver, in this way ensuring membrane integrity, along with diminishing enzymatic leakage (Jadon et al., 2007).

A significant increment in the level of serum bilirubin was seen in DEN administered mice, which might be due to mass hindrance of the conjugation response and releaseof unconjugated bilirubin from damaged hepatocytes (Rajkapoor et al., 2006). Decline in serum bilirubin after treatment with $B$. ciliata demonstrated the viability of the plant in keeping up the healthy status of the liver.

Five nucleotidase is a fundamental protein in the extracellular pathway, since it produces adenosine from AMP and is communicated in a wide range of tissues (Zimmermann, 1992). Studies confirm that elevation of 5-nucleotidase is related with an exceedingly obtrusive phenotype (Sadej et al., 2006), tranquilize resistance and tumor-advancing capacities (Ujházy et al., 1996). Besides producing adenosine, 5-nucleotidase may take part in bonding and interacting with extracellular matrix proteins. Adenosine is accounted for to be available at high levels in strong tumors, with high concentration in extracellular tumor microenvironment and is accounted for tumor development and angiogenesis (Spychala, 2000). Extracts of $B$. ciliata treatment significantly diminished the levels of 5-nucleotidase in serum, which may be because of the capacity of the molecules in B. ciliata to successfully restrain expansion.

Gamma-glutamyl transferase (YGT) is a membrane bound enzyme, which shows a tissue specific expression and is modified under different physiologic and pathologic conditions, for example, development and carcinogenesis (Yao et al., 2004). It is most elevated in developing fetus livers and declines quickly to the least levels after birth, and is a enzyme that has been widely examined in connection to hepatocarcinogenesis. A few reviews have shown that YGT level was elevated during development of HCC, which may demonstrate the fundamental tumor load (Tang et al., 1999). Though, B. ciliata treated mice demonstrated diminished level of YGT in contrasted to tumor-bearing mice, which shows diminished tumor load in $B$. ciliata treated mice.

AFP is a well-known representative tumor marker of HCC. High levels of AFP are believed to be strongly suggestive of HCC (Endo et al., 1975) because greater than seventy percent of HCC patients have high serum concentration of AFP because of the tumor secretion. AFP is also most extensively used in the diagnosis of HCC (Ramakrishnan et al., 2007). The increased level of AFP observed in DEN-induced animals is an indicative of HCC. Extract of $B$. Ciliatatreatment significantly reduced the levels of AFP, which revealed the anti-tumor effect of the $B$. ciliata against HCC.

Information exhibited in the present research shows that DEN altogether diminished serum albumin. Vandenberghe (1996) revealed that, hypoalbuminemia may be result of liver damage, which is associated with decrease in albumin synthesis. Cross et al. (1987) ascribed the hypoalbuminemia state to the increased rate of catabolism as compared to disability of synthesis. Due to the toxic effect of cancer causing agents; there is an increased production of ROS. These free radicals are equipped for harming biomolecules, for example, proteins that affect cell activities, membrane capacities and structure. Treatment of $B$. ciliata returned the albumin level to ordinary, which mirrors the well working of hepatocytes protein.

Glucose-6-phosphate dehydrogenase (G6PDH) is the key enzyme that catalyses the first step of the pentose phosphate pathway to produce NADPH and ribose-5-phosphate (Ulusu and Tandogan, 2006). This regulatory house-keeping enzyme is localized to the cytosol and mitochondria and is an antioxidant that preserves the cytosolic redox status by producing the cellular reductant, NADPH (Jain et al., 2003; Frederiks et al., 2003; Stanton et al., 1991). The literature suggests that under proliferative conditions, G6PD gene expression increases both in foetal hepatocytes (Molero et al., 1994) and in cultured mature liver cells (Stanton, 2012). Our results based on the biochemical parameters are consistent with previous reports in which DEN shows a significant increase in LFT proteins due to hepatic intoxication (Mukherjee and Ahmad, 2015; Latha and Latha, 2014). B. ciliata treatment returned the levels of G6PDH to normal levels in DEN treated mice. Therefore, $B$. ciliata administration seems to be a highly promising agent for protecting hepatic tissue against oxidative damage and in preventing hepatic injury and dysfunction.

\section{Conclusion}

Hepatocellular carcinoma is highly aggressive cancer, characterized by rapid growth and early vascular invasion. Present study proposed that besides various chemotherapeutic drugs are being used for the treatment of $\mathrm{HCC}$, the vital role was played by $B$. ciliata in prevention and treatment of hepatocellular carcinoma. Methanolic extracts of $B$. ciliata contains cytotoxic effects and have apoptotic properties against hepatocellular carcinoma 
in vivo. B. ciliata decreased the levels of tumor markers: aspartate aminotransferase, alanine aminotransferase, lactate dehydrogenase, alpha-fetoprotein, gamma glutamyl transferase, 5' nucleotidase and glucose-6-phosphate dehydrogenase. It was concluded that bioactive compounds $B$. ciliata is a source of anticancer drug.

\section{Acknowledgements}

Authors are grateful to Azad Jammu and Kashmir University for providing funds for this study.

\section{References}

ANIS, K.V., RAJESHKUMAR, N. and KUTTAN, R., 2001. Inhibition of chemical carcinogenesis by berberine in rats and mice.The Journal of Pharmacy and Pharmacology, vol. 53, no. 5, pp. 763-768. http://dx.doi.org/10.1211/0022357011775901. PMid:11370717.

ANSIL, S., BAKHTIARY, M.K. and GOODARZI, M., 2012. Congenital sternal foramen in a stillborn Holstein calf.Asian Pacific journal of tropical biomedicine, vol. 2, no. 1, pp. 83-84. http:// dx.doi.org/10.1016/S2221-1691(12)60135-X. PMid:23569841.

BANSAL, A.K., BANSAL, M., SONI, G. and BHATNAGAR, D., 2005. Protective role of Vitamin E pretreatment on $\mathrm{N}$-nitrosodiethylamine induced oxidative stress in rat liver. Chemico-Biological Interactions, vol. 156, no. 2-3, pp. 101-111. http://dx.doi.org/10.1016/j.cbi.2005.08.001. PMid:16144695.

BARTSCH, H. and MONTESANO, R., 1984. Relevance of nitrosoamines to human cancer.Carcinogenesis, vol. 5, no. 11, pp. 1381-1393. http://dx.doi.org/10.1093/carcin/5.11.1381. PMid:6386215.

BRUNO, S., BATTEZZATI, P.M., BELLATI, G., MANZIN, A., MAGGIONI, M., CROSIGNANI, A., BORZIO, M., SOLFOROSI, L., MORABITO, A., IDEO, G. and PODDA, M., 2001. Long-term beneficial effects in sustained responders to interferon-alfa therapy for chronic hepatitis C.Journal of Hepatology, vol. 34, no. 5, pp. 748-755. http://dx.doi.org/10.1016/ S0168-8278(01)00062-9. PMid:11434622.

CHEN, G., WANG, K., YANG, B.Y., TANG, B., CHEN, J.X. and HUA, Z.C., 2012. Synergistic antitumor activity of oridonin and arsenic trioxide on hepatocellular carcinoma cells.International Journal of Oncology, vol. 40, no. 1, pp. 139-147. PMid:21947421.

CHEN, Z.F., TAN, M.X., LIU, Y.C., PENG, Y., WANG, H.H., LIU, H.G. and LIANG, H., 2011. Synthesis, characterization and preliminary cytotoxicity evaluation of five Lanthanide (III)-Plumbagin complexes.Journal of Inorganic Biochemistry, vol. 105, no. 3 , pp. 426-434. http://dx.doi.org/10.1016/j.jinorgbio.2010.12.003. PMid:21421129.

CHUNG, V., 2015. Systemic therapy for hepatocellular carcinoma and cholangiocarcinoma.Surgical Oncology Clinics, vol. 24, no. 1, pp. 187-198. PMid:25444475.

COTRIM, H.P., PARANÁ, R., BRAGA, E. and LYRA, L., 2000. Nonalcoholic steatohepatitis and hepatocellular carcinoma: natural history.The American Journal of Gastroenterology, vol. 95, no. 10, pp. 3018-3019. http://dx.doi.org/10.1111/j.15720241.2000.03241.x. PMid:11051414.

CROSS, C.E., HALLIWELL, B., BORISH, E.T., PRYOR, W.A., AMES, B.N., SAUL, R.L., MCCORD, J.M. and
HARMAN, D., 1987. Oxygen radicals and human disease.Annals of Internal Medicine, vol. 107, no. 4, pp. 526-545. http://dx.doi. org/10.7326/0003-4819-107-4-526. PMid:3307585.

DANGERFIELD, W.G. and FINLAYSON, R., 1953. Estimation of bilirubin in serum.Journal of Clinical Pathology, vol. 6, no. 3, pp. 173-177. http://dx.doi.org/10.1136/jcp.6.3.173. PMid:13084758.

DENG, G.L., ZENG, S. and SHEN, H., 2015. Chemotherapy and target therapy for hepatocellular carcinoma: New advances and challenges.World Journal of Hepatology, vol. 7, no. 5, pp. 787-798. http://dx.doi.org/10.4254/wjh.v7.i5.787. PMid:25914779.

DONATO, F., TAGGER, A., GELATTI, U., PARRINELLO, G., BOFFETTA, P., ALBERTINI, A., DECARLI, A., TREVISI, P., RIBERO, M., MARTELLI, C., PORRU, S. and NARDI, G., 2002. Alcohol and hepatocellular carcinoma: the effect of lifetime intake and hepatitis virus infections in men and women.American Journal of Epidemiology, vol. 155, no. 4, pp. 323-331. http:// dx.doi.org/10.1093/aje/155.4.323. PMid:11836196.

EL-SERAG, H.B. and RUDOLPH, K.L., 2007. Hepatocellular carcinoma: epidemiology and molecular carcinogenesis. Gastroenterology, vol. 132, no. 7, pp. 2557-2576. http://dx.doi. org/10.1053/j.gastro.2007.04.061. PMid:17570226.

ENDO, Y., KANAI, K., ODA, T., MITAMURA, K., IINO, S. and SUZUKI, H., 1975. Clinical significance of $\alpha$-fetoprotein in hepatitis and liver cirrhosis.Annals of the New York Academy of Sciences, vol. 259, no. 1, pp. 234-238. http://dx.doi. org/10.1111/j.1749-6632.1975.tb25418.x. PMid:54025.

FREDERIKS, W.M., BOSCH, K.S., JONG, J.S. and VAN NOORDEN, C.J., 2003. Post-translational regulation of glucose6-phosphate dehydrogenase activity in (pre) neoplastic lesions in rat liver.The Journal of Histochemistry and Cytochemistry, vol. 51, no. 1, pp. 105-112. http://dx.doi.org/10.1177/002215540305100112. PMid:12502759.

HAFIDH, R., ABDULAMIR, A., JAHANSHIRI, F., ABAS, F., BAKAR, F.A. and SEKAWI, Z., 2009. Asia is the mine of natural antiviral products for public health.The Open Complementary Medicine Journal, vol. 1, pp. 58-68.

HARPER, H.A., 1961. The functions and tests of the liver. In: H.A.HARPER, V.W.RODWELL and P.A.MAYES. Review of physiological chemistry. Los Altos: Lange Medical Publishers, pp. 271-283.

HUSSAIN, T., SIDDIQUI, H.H., FAREED, S., VIJAYAKUMAR, M. and RAO, C.V., 2012. Evaluation of chemopreventive effect of Fumaria indica against $\mathrm{N}$-nitrosodiethylamine and $\mathrm{CCl} 4$ induced hepatocellular carcinoma in Wistar rats.Asian Pacific Journal of Tropical Medicine, vol. 5, no. 8, pp. 623-629. http:// dx.doi.org/10.1016/S1995-7645(12)60128-X. PMid:22840450.

IKEDA, K., SAITOH, S., ARASE, Y., CHAYAMA, K., SUZUKI, Y., KOBAYASHI, M., TSUBOTA, A., NAKAMURA, I., MURASHIMA, N., KUMADA, H. and KAWANISHI, M., 1999. Effect of interferon therapy on hepatocellular carcinogenesis in patients with chronic hepatitis type C: A long-term observation study of 1,643 patients using statistical bias correction with proportional hazard analysis. Hepatology, vol. 29, no. 4, pp. 11241130. http://dx.doi.org/10.1002/hep.510290439. PMid:10094956.

JADON, A., BHADAURIA, M. and SHUKLA, S., 2007. Protective effect of Terminalia belerica Roxb and gallic acid against carbon tetrachloride induced damage in albino rats.Journal of Ethnopharmacology, vol. 109, no. 2, pp. 214-218. http://dx.doi. org/10.1016/j.jep.2006.07.033. PMid:17049775. 
JAIN, M., BRENNER, D.A., CUI, L., LIM, C.C., WANG, B., PIMENTEL, D.R., KOH, S., SAWYER, D.B., LEOPOLD, J.A., HANDY, D.E., LOSCALZO, J., APSTEIN, C.S. and LIAO, R., 2003. Glucose-6-phosphate dehydrogenase modulates cytosolic redox status and contractile phenotype in adult cardiomyocytes. Circulation Research, vol. 93, no. 2, pp. e9-16. http://dx.doi. org/10.1161/01.RES.0000083489.83704.76. PMid:12829617.

JEMAL, D.V.M.A., SIEGEL, R., WARD, E., MURRAY, T., XU, J. and THUN, M.J., 2007. Cancer statistics.CA: a Cancer Journal for Clinicians, vol. 57, no. 1, pp. 43-66. http://dx.doi. org/10.3322/canjclin.57.1.43. PMid:17237035.

KIM, H.J., PARK, S.Y., LEE, H.M., SEO, D.I. and KIM, Y.M., 2015. Antiproliferative effect of the methanol extract from the roots of Petasites japonicus on Hep3B hepatocellular carcinoma cells in vitro and in vivo. Experimental and Therapeutic Medicine, vol. 9, no. 5, pp. 1791-1796. http://dx.doi.org/10.3892/etm.2015.2296. PMid:26136894

KING, J., 1965. The dehydrogenases or oxido reductaselactatedehydrogenase. In: J.KING, ed. Practical clinical enzymology. London: D Van Nostrand Company Ltd, pp. 83-93.

LATHA, B. and LATHA, M., 2014. Preventive effect of Leucas aspera methanolic extract on $\mathrm{N}^{\prime}$-Nitrosodiethylamine induced sub-acute liver toxicity in male wistar rats.International Journal of Pharmaceutical Sciences Review and Research, vol. 5, no. 6, pp. 2349.

LI, Y., SHI, X., ZHANG, J., ZHANG, X. and MARTIN, R.C., 2014. Hepatic protection and anticancer activity of curcuma: a potential chemopreventive strategy against hepatocellular carcinoma.International Journal of Oncology, vol. 44, no. 2, pp. 505-513. http://dx.doi.org/10.3892/ijo.2013.2184. PMid:24270742.

MACNAB, G.M., URBANOWICZ, J.M. and KEW, M.C., 1978. Carcinoembryonic antigen in hepatocellular cancer.British Journal of Cancer, vol. 38, no. 1, pp. 51-54. http://dx.doi.org/10.1038/ bjc.1978.162. PMid:80223.

MCMAHON, B.J., ALBERTS, S.R., WAINWRIGHT, R.B., BULKOW, L. and LANIER, A.P., 1990. Hepatitis B related sequelae: prospective study in 1400 hepatitis B surface antigen positive Alaska native carriers.Archives of Internal Medicine, vol. 150, no. 5, pp. 1051-1054. http://dx.doi.org/10.1001/ archinte.1990.00390170087019. PMid:2158773.

MINUCCI, A., GIARDINA, B., ZUPPI, C. and CAPOLUONGO, E., 2009. Glucose-6-phosphate dehydrogenase laboratory assay: How, when, and why?IUBMB Life, vol. 61, no. 1, pp. 27-34. http:// dx.doi.org/10.1002/iub.137. PMid:18942156.

MITTAL, G., BRAR, A.P.S. and SONI, G., 2006. Impact of hypercholesterolemia on toxicity of N-nitrosodiethylamine: biochemical and histopathological effects.Pharmacological Reports, vol. 58, no. 3, pp. 413-419. PMid:16845216.

MOLERO, C., BENITO, M. and LORENZO, M., 1994. Glucose6-phosphate dehydrogenase gene expression in fetal hepatocyte primary cultures under nonproliferative and proliferative conditions. Experimental Cell Research, vol. 210, no. 1, pp. 26-32. http:// dx.doi.org/10.1006/excr.1994.1004. PMid:8269993.

MUKHERJEE, D. and AHMAD, R., 2015. Glucose-6-phosphate Dehydrogenase Activity during N'-nitrosodiethylamine-induced Hepatic Damage.Achievements in the Life Sciences, vol. 9, no. 1, pp. 51-56. http://dx.doi.org/10.1016/j.als.2015.05.007.
RHOADES, R. A. and BELL, D. R., 2013. Medical physiology: principles for clinical medicine. 4th ed. Philadelphia: Lippincott Williams \& Wilkins. Liver physiology, pp. 536-549.

RAJKAPOOR, B., JAYAKAR, B., MURUGESH, N. and SAKTHISEKARAN, D., 2006. Chemoprevention and cytotoxic effect of Bauhinia variegata against $\mathrm{N}$-nitrosodiethylamine induced liver tumors and human cancer cell lines.Journal of Ethnopharmacology, vol. 104, no. 3, pp. 407-409. http://dx.doi. org/10.1016/j.jep.2005.08.074. PMid:16257158.

RAMAKRISHNAN, G., AUGUSTINE, T., JAGAN, S., VINODHKUMAR, R. and DEVAKI, T., 2007. Effect of silymarin on N-nitrosodiethylamine induced hepatocarcinogenesis in rats. Experimental Oncology, vol. 29, no. 1, pp. 39-44. PMid:17431387.

REITMAN, S. and FRANKEL, S., 1957. A colorimetric method for the determination of serum glutamic oxalacetic and glutamic pyruvic transaminases.American journal of clinical pathology, vol. 28, no. 1, pp. 56-63. http://dx.doi.org/10.1093/ajcp/28.1.56. PMid:13458125.

RIEDER, S.V. and OTERO, M., 1969. A simplified procedure for the assay of 5'-Nucleotidase.Clinical Chemistry, vol. 15, no. 8, pp. 727-729. PMid:4309139.

RUBY, K., CHAUHAN, R., SHARMA, S. and DWIVEDI, J., 2012. Polypharmacological activities of Bergenia species. International Journal of Pharmaceutical Sciences Review and Research, vol. 13, no. 1, pp. 100-109.

SADEJ, R., SPYCHALA, J. and SKLADANOWSKI, A.C., 2006. Expression of ecto-5'-nucleotidase (eN, CD73) in cell lines from various stages of human melanoma.Melanoma Research, vol. 16, no. 3, pp. 213-222. http://dx.doi.org/10.1097/01. cmr.0000215030.69823.11. PMid:16718268.

SAVORY, J., HEINTGES, M.G., SONOWANE, M. and CROSS, R.E., 1976. Measurement of total protein and albumin in serum with centrifugal analyser.Clinical Chemistry, vol. 22, no. 7, pp. 1102-1104. PMid:1277510.

SELL, S. and BECKER, F.F., 1978. Alpha-Fetoprotein.Journal of the National Cancer Institute, vol. 60, no. 1, pp. 19-26. http:// dx.doi.org/10.1093/jnci/60.1.19. PMid:75267.

SPYCHALA, J., 2000. Tumor promoting functions of adenosine. Pharmacology \& Therapeutics, vol. 87, no. 2-3, pp. 161-173. http:// dx.doi.org/10.1016/S0163-7258(00)00053-X. PMid:11007998.

STANTON, R.C., 2012. Glucose-6-phosphate dehydrogenase, NADPH and cell survival.IUBMB Life, vol. 64, no. 5, pp. 362-369. http://dx.doi.org/10.1002/iub.1017. PMid:22431005.

STANTON, R.C., SEIFTER, J., BOXER, D.C., ZIMMERMAN, E. and CANTLEY, L., 1991. Rapid release of bound glucose6-phosphate dehydrogenase by growth factors. Correlation with increased enzymatic activity.The Journal of Biological Chemistry, vol. 266, no. 19, pp. 12442-12448. PMid:2061319.

SWENBERG, J.A., HOEL, D.G. and MAGEE, P.N., 1991. Mechanistic and statistical insight into the large carcinogenesis bioassays on $\mathrm{N}$-nitrosodiethylamine and $\mathrm{N}$-nitrosodimethylamine. Cancer Research, vol. 51, no. 23, pt. 2, pp. 6409-6414. PMid:1933905.

SZASZ, G., 1976. Reaction rate method for gamma glutamyl transferase activity in serum.Clinical Chemistry, vol. 22, no. 12, pp. 2051-2055. PMid:11903.

TANG, Q.Y., YAO, D.F., LU, J.X., WU, X.H. and MENG, X.Y., 1999. Expression and alterations of different molecular form $\gamma$-glutamyl transferase and total RNA concentration during the 
carcinogenesis of rat hepatoma. World Journal of Gastroenterology, vol. 5, no. 4, pp. 356-358. http://dx.doi.org/10.3748/wjg.v5.i4.356. PMid:11819467.

TEPPERMAN, H.M. and TEPPERMAN, J., 1962. Role of hormones in glucose-6-phosphate dehydrogenase adaptation of rat liver.The American Journal of Physiology, vol. 202, no. 3, pp. 401-406. http://dx.doi.org/10.1152/ajplegacy.1962.202.3.401. PMid:13920275.

TURNER, P.C., SYLLA, A., DIALLO, M.S., CASTEGNARO, J.J., HALL, A.J. and WILD, C.P., 2002. The role of aflatoxins and hepatitis viruses in the etiopathogenesis of hepatocellular carcinoma: A basis for primary prevention in Guinea, Conakry and West Africa.Journal of Gastroenterology and Hepatology, vol. 17, no. 4, suppl., pp. S441-S448. http://dx.doi.org/10.1046/j.1440-1746.17. s4.7.x. PMid:12534775.

UJHÁZY, P., BERLETH, E.S., PIETKIEWICZ, J.M., KITANO, H., SKAAR, J.R., EHRKE, M.J. and MIHICH, E., 1996. Evidence for the involvement of ecto-5'-nucleotidase (CD73) in drug resistance.International Journal of Cancer, vol. 68, no. 4, pp. 493-500. http://dx.doi.org/10.1002/(SICI)10970215(19961115)68:4<493::AID-IJC15>3.0.CO;2-6. PMid:8945621.

ULUSU, N.N. and TANDOGAN, B.T., 2006. Purification and kinetics of sheep kidney cortex glucose-6-phosphate dehydrogenase. Comparative Biochemistry and Physiology. Part B, Biochemistry \& Molecular Biology, vol. 143, no. 2, pp. 249-255. http://dx.doi. org/10.1016/j.cbpb.2005.11.018. PMid:16406826.

USUNOMENA, U., ADEMUYIWA, A.J., TINUADE, O.O., UDUENEVWO, F.E., MARTIN, O. and OKOLIE, N., 2012. Nitrosodimethylamine NDMA, liver function enzymes, renal function parameters and oxidative stress parameters: a review. British Journal of Pharmacology and Toxicology, vol. 3, no. 4, pp. $165-176$

VANDENBERGHE, J., 1996. Hepatotoxicology: structure, function and toxicological pathology. In: R.J.M.NIESINK, J.VRIES and M.A.HOLLINGER, eds. Toxicology: principles and applications. Boca Raton: CRC, pp. 668-701.

VOZAROVA, B., STEFAN, N., LINDSAY, R.S., SAREMI, A., PRATLEY, R.E., BOGARDUS, C. and TATARANNI, P.A., 2002. High alanine aminotransferase is associated with decreased hepatic insulin sensitivity and predicts the development of type 2 diabetes.Diabetes, vol. 51, no. 6, pp. 1889-1895. http://dx.doi. org/10.2337/diabetes.51.6.1889. PMid:12031978.
WANG, W.Q., LIU, L., SUN, H.C., FU, Y.L., XU, H.X., CHAI, Z.T., ZHANG, Q.B., KONG, L.Q., ZHU, X.D., LU, L., REN, Z.G. and TANG, Z.Y., 2012. Tanshinone IIA inhibits metastasis after palliative resection of hepatocellular carcinoma and prolongs survival in part via vascular normalization.Journal of Hematology \& Oncology, vol. 5, pp. 69. PMid:23137165.

WHITTBY, L.G., PEREY-ROBB, I.W. and SMITH, A.T., 1984. Plasma enzymes tests in diagnosis. In: L.G.WHITTBY, ed. Lecture notes in clinical biochemistry. 3rd ed. Oxford, Boston: Black Well Scientific Publications, pp. 138-169.

WOLK, A., GRIDLEY, G., SVENSSON, M., NYRÉN, O., MCLAUGHLIN, J.K., FRAUMENI, J.F. and ADAM, H.O., 2001. A prospective study of obesity and cancer risk (Sweden). Cancer Causes \& Control, vol. 12, no. 1, pp. 13-21. http://dx.doi. org/10.1023/A:1008995217664. PMid:11227921.

YAO, D.F., DONG, Z.Z., YAO, D.B., WU, X.H., WU, W., QIU, L.W., WANG, H.M. and MENG, X.Y., 2004. Abnormal expression of hepatoma-derived gamma glutamyltransferase subtyping and its early alteration for carcinogenesis of hepatocytes. Hepatobiliary \& Pancreatic Diseases International, vol. 3, no. 4, pp. 564-570. PMid:15567746.

YU, M.C. and YUAN, J.M., 2004. Environmental factors and risk for hepatocellular carcinoma.Gastroenterology, vol. 127, no. 5, suppl. 1, pp. S72-S78. http://dx.doi.org/10.1016/j. gastro.2004.09.018. PMid:15508106.

ZIMMERMANN, H., 1992. 5'-Nucleotidase: molecular structure and functional aspects. The Biochemical Journal, vol. 285, no. 2, pp. 345-365. http://dx.doi.org/10.1042/bj2850345. PMid:1637327.

\section{Authors contributions}

Kamaran Khurshid Dar and Shaukat Ali proposed the thought and framework of this paper and wrote this paper. Shukat Ali implemented the thought with software, analyzed the data. Mubashair Ejaz, Sundas Nasreen, Fiza Gillani, Sobia Safeer and Naheeda Shafi maintained animals in Lab, Muhammad Adeeb Khan and Tafail Akbar Mughal provided medical guidance of this paper, Saiqa Andleeb provided guidance in preparation of extracts. All authors read and approved the final manuscript. 